\title{
PENGARUH KOMITMEN, KUALITAS SUMBER DAYA MANUSIA, GAYA KEPEMIMPINAN TERHADAP KEMAMPUAN PENYUSUNAN ANGGARAN PADA PEMERINTAH KOTA MANADO
}

\author{
Peggy Rumenser \\ (email: peggyrumenser@yahoo.com)
}

\begin{abstract}
The implementation of the local government can not be separated from the budget. In Regulation No. 13 of 2006, the draft budget work units contained in a document called the Draft Budget Unit (Rask). Rask standard includes expenditure analysis, a benchmark of the performance of standard costs as the principal instrument in the budget performance. The budget is important because it is used in the allocation of funds for the implementation of local government activities. In budgeting involvement of various work units (SKPD) in Manado City Government is indispensable. This is to improve the effectiveness and efficiency of governance and public service. This study aims to analyze Effect of Commitment, Quality of Human Resources, Leadership Style, to the ability of Local Government Budgeting in Manado.

Sources of data in this study are primary data and secondary data in the form of a questionnaire. The population in this study is the employee on education (Department and Agency) Manado, and in this study the sampling method used was judgment sampling, the sample in this study is the Secretary, Head of Division (third tier). Data used in this study is mainly qualitative data were quantified by using multiple regression analysis. To test the quality of the data with validity and reliability. Besides testing the classical assumption of normality, multicollinearity and heteroscedasticity.

The research proves that in partial Commitment, Quality of Human Resources does not affect the ability of Budgeting in Local Government Leadership Style Manado while variable positive effect on the ability of Local Government Budgeting in Manado.
\end{abstract}

Keywords : Effect of Commitment, Quality of Human Resources, Leadership Style, to the ability of Local Government Budgeting In the city of Manado

\section{PENDAHULUAN}

Penyelenggaraan pemerintah daerah tak terlepas dari anggaran. Dalam Permendagri Nomor 13 Tahun 2006, rancangan anggaran unit kerja dimuat dalam suatu dokumen yang disebut Rancangan Anggaran Satuan Kerja (RASK). RASK memuat standar analisis belanja, tolak ukur kinerja standar biaya sebagai intrumen pokok dalam anggaran kinerja. Untuk peningkatan kompetensi aparat pengelola APBD, Menteri Dalam Negeri mengeluarkan Permendagri Nomor 27 Tahun 2013 tentang Pedoman Penyusunan APBD Tahun 2014.

Di dalam penyusunan anggaran keterlibatan berbagai Satuan Kerja Perangkat Daerah (SKPD) di Pemerintah Daerah Kota Manado sangat diperlukan. Hal ini untuk meningkatkan daya guna dan hasil guna penyelenggaraan pemerintahan dan pelayanan masyarakat. Untuk mewujudkan hal tersebut Pemerintah Kota Manado menetapkan dalam salah satu sasaran yang akan dicapai dalam Rencana Pembangunan Jangka Menengah Daerah (RPJMD) yaitu menerapkan tata kelola pemerintahan yang Baik dan Bersih,

Berdasarkan Pemeriksaan Badan Pemeriksa Keuangan (BPK) RI terhadap Laporan Keuangan Pemerintah Daerah (LKPD) Kota Manado. Tabel 1.1 memperlihatkan opini yang diberikan BPK RI atas Badan Pemeriksa Keuangan (BPK) RI memberikan Opini atas Laporan Keuangan Pemerintah Daerah (LKPD) Kota Manado. Dari Tahun 2008 hingga 2011 masih belum sesuai dengan apa yang diharapkan sehingga perlu peningkatan dalam pengelolaan keuangan daerah. Selanjutnya untuk 2012 hingga 2013 Opini Badan Pemeriksa Keuangan (BPK) RI yang diberikan kepada Pemerintah Kota Manado sudah lebih baik dengan Opini Wajar dengan Pengecualian (WDP). 
Masalah yang dapat dirumuskan dalam penelitian ini adalah Apakah ada pengaruh dari ketiga variabel, Komitmen, Kualitas Sumber Daya Manusia, Gaya Kepemimpinan terhadap Kemampuan Penyusunan Anggaran Pemerintah Kota Manado?

Berdasarkan latar belakang masalah dan rumusan masalah yang telah diuraikan, maka tujuan penelitian ini adalah sebagai berikut.Untuk menganalisis pengaruh Komitmen, Kualitas Sumber Daya Manusia, Gaya Kepemimpinan terhadap Kemampuan Penyusunan Anggaran Pemerintah Kota Manado.

\section{LANDASAN TEORI \\ Teori Atribusi}

Teori atribusi menyatakan bahwa bila individu-individu mengamati perilaku seseorang, mereka mencoba untuk menentukan apakah itu ditimbulkan secara internal atau eksternal Robbins dikutip oleh Jatmiko (2006;35). Perilaku yang disebabkan secara internal adalah perilaku yang diyakini berada di bawah kendali pribadi individu itu sendiri, sedangkan perilaku yang disebabkan secara eksternal adalah perilaku yang dipengaruhi dari luar, artinya individu akan terpaksa berperilaku karena situasi.

\section{Theory of Planned Behaviour (TPB)}

Theory of Planned Behavior (TPB) dikutip oleh Putri (2013; 24 ) merupakan pengembangan dari Theory of Reasoned Action (TRA) yang bertujuan untuk memperlihatkan hubungan dari perilaku-perilaku yang dimunculkan oleh individu untuk menanggapi sesuatu. Dalam TPB ditambahkan satu variabel yaitu kontrol keperilakuan yang dipersepsikan yang belum dijelaskan dalam TRA. Adanya variabel kontrol keperilakuan yang dipersepsikan berarti bahwa tidak semua tindakan yang diambil oleh individu berada di bawah kendali individu tersebut.

\section{Teori Pemerintahan yang Baik (Good Governance)}

Undang-Undang Nomor 28 tahun 1999, maka asas-asas umum pemerintahan yang baik di Indonesia diidentifikasikan dalam Pasal 3 dan Penjelasanya yang dirumuskan sebagai asas umum penyelenggaraan negara. Asas ini terdiri dari berikut ini

1. Asas Kepastian Hukum, yaitu asas dalam negara hukum yang mengutamakan landasan peraturan perundang-undangan, kepatutan, dan keadilan dalam setiap kebijakan Penyelenggara Negara.

2. Asas Tertib Penyelenggaraan Negara, yaitu asas yang menjadi landasan keteraturan, keserasian, dan keseimbangan dalam pengendalian penyelenggaraan negara.

3. Asas Kepentingan Umum, yaitu asas yang mendahulukan kesejahteraan umum dengan cara yang aspiratif, akomodatif, dan selektif.

4. Asas Keterbukaan, yaitu asas yang membuka diri terhadap hak masyarakat untuk memperoleh informasi yang benar, jujur, dan tidak diskriminatif tentang penyelenggaraan negara dengan tetap memperhatikan perlindungan atas hak asasi pribadi, golongan, dan rahasia negara.

5. Asas Proporsionalitas, yaitu asas yang mengutamakan keseimbangan antara hak dan kewajiban Penyelenggara Negara.

6. Asas Profesionalitas, yaitu asas yang mengutamakan keahlian yang berlandaskan kode etik dan ketentuan peraturan perundang-undangan yang berlaku.

7. Asas Akuntabilitas, yaitu asas yang menentukan bahwa setiap kegiatan dan hasil akhir dari kegiatan Penyelenggara Negara harus dapat dipertanggungjawabkan kepada masyarakat atau rakyat sebagai pemegang kedaulatan tertinggi negara sesuai dengan ketentuan peraturan perundang-undangan yang berlaku.

\section{Konsep Anggaran Sektor Publik}

Menurut Bastian (2006:164), jenis anggaran sektor publik terbagi dua, yaitu Anggaran Negara dan Daerah (APBN/APBD), serta Rencana Kegiatan Anggaran Perusahaan (RKAP), yaitu anggaran usaha setiap BUMN/BUMD serta badan hukum publik atau gabungan publik-swasta. Selanjutnya anggaran berfungsi sebagai berikut.

1. Anggaran merupakan hasil akhir proses penyusunan rencana kerja,

2. Anggaran merupakan cetak biru aktivitas yang akan dilaksanakan dimasa mendatang,

3. Anggaran sebagai alat komunikasi intern yang menghubungkan berbagai unit kerja dan mekanisme kerja antara atasan dan bawahan,

4. Anggaran sebagai alat pengendalian unit kerja, 
5. Anggaran sebagai alat motivasi dan persuasi tindakan efektif dan efisien dalam pencapaian visi organisasi,

6. Anggaran merupakan instrument politik,

7. Anggaran merupakan instrument kebijakan fiskal.

Secara tradisional, prinsip penganggarannyang sangat terkenal adalah apa yang dikenal dengan 3E, yaitu Ekonomis, Efektif dan Efisien (Jones dan Pendlebury, 1988). Mereka menjelaskan bahwa ekonomis hanya berkaitan dengan input, efektifitas hanya berkaitan dengan ouput, sedangkan efisiensi adalah kaitan antara ouput dan input.

\section{Konsep Penganggaran Daerah}

Dalam Permendagri Nomor 13 Tahun 2006, keuangan daerah adalah semua hak dan kewajiban daerah yang dapat dinilai dengan uang termasuk didalamnya segala bentuk kekayaan yang berhubungan dengan hak dan kewajiban daerah tersebut. APBD adalah rencana keuangan tahunan pemerintahan daerah yang dibahas dan disetujui bersama oleh pemerintah daerah dan DPRD, dan ditetapkan dengan peraturan daerah. RKA SKPD merupakan dokumen perencanaan dan penganggaran yang berisi rencana pendapatan rencana belanja program dan kegiatan SKPD serta rencana pembiayaan sebagai dasar penyusunan APBD.

Pedoman penyusunan RKA-SKPD disusun dengan menggunakan pendekatan kerangka pengeluaran jangka menengah daerah, penganggaran terpadu dan penganggaran berdasarkan prestasi kerja (Permendagri Nomor 13 Tahun 2006).Untuk terlaksananya penyusunan RKA-SKPD dan terciptanya kesinambungan RKA-SKPD, maka kepala SKPD mengevaluasi hasil pelaksanaan program dan kegiatan 2 (dua) tahun anggaran sebelumnya sampai dengan semester pertama tahun anggaran berjalan. Evaluasi bertujuan menilai program dan kegiatan yang belum dapat dilaksanakan dan/atau diselesaikan pada tahun-tahun sebelumnya untuk dilaksanakan dan/atau deselesaikan pada tahun yang direncanakan atau 1 (satu) tahun berikutnya dari tahun yang direncanakan. Penganggaran daerah dengan pendekatan penganggaran merupakan tolak ukur kinerja dalam menentukan capaian jenis dan mutu pelayanan dasar yang merupakan urusan wajib daerah.

\section{Hubungan Komitmen terhadap Kemampuan Penyusunan Anggaran Pemerintah Daerah}

Mathis dan Jackson dikutip oleh Sopiah (2008 : 155) mendefinisikan komitmen organisasional sebagai derajat dimana karyawan percaya dan mau menerima tujuan-tujuan organisasi dan akan tetap tinggal atau tidak akan meninggalkan organisasinya.

Menurut Simanjutak dikutip oleh Azhar (2007), komitmen adalah kesanggupan untuk bertanggungjawab terhadap hal - hal yang dipercayakan kepada seseorang. Komitmen tidak ada hubungannya sama sekali dengan bakat, kepintaran atau talenta. Dengan komitmen yang kuat akan memungkinkan seseorang bisa mengeluarkan daya fisik, mental dan spiritual tambahan yang bisa diperoleh, sebaliknya tanpa komitmen maka pekerjaan - pekerjaan besar akan sulit dilaksanakan.

Komitmen terhadap organisasi artinya lebih dari sekedar keanggotaan formal, karena meliputi sikap menyukai organisasi dan kesediaan untuk mengusahakan tingkat upaya yang tinggi bagi kepentingan organisasi demi pencapaian tujuan. Berdasarkan definisi ini, dalam komitmen organisasi tercakup unsur loyalitas terhadap organisasi, keterlibatan dalam pekerjaan dan identifikasi terhadap nilai nilai dan tujuan organisasi. Rendahnya komitmen mencerminkan kurangnya tanggung jawab seseorang dalam menjalankan tugasnya. Mempersoalkan komitmen sama dengan mempersoalkan tanggung jawab.

\section{Hubungan Kualitas Sumber Daya Manusia terhadap Kemampuan Penyusunan Anggaran Pemerintah Daerah}

Menurut Azhar (2007), sumber daya manusia adalah kesatuan tenaga manusia yang dalam organisasi dan bukan hanya sekedar pejumlahan karyawan- karyawan yang ada. Sebagai kesatuan, sumber daya manusia harus dipandang sebagai suatu sistem di mana tiap-tiap karyawan berfungsi untuk mencapai tujuan organisasi. Sumber daya manusia diukur berdasarkan latar belakang pendidikan yang diperoleh pegawai. Dalam kaitan dengan kemampuan penyusunan anggaran, maka efektif dalam 
penyusunan anggaran adalah sumber manusia yakni pegawai yang memiliki latar belakang pendidikan Akuntansi, Keuangan dan pegawai yang sudah memiliki pengalaman dengan waktu yang relatif lama di bidang penganggaran.

\section{Hubungan Gaya Kepemimpinan terhadap Kemampuan Penyusunan Anggaran Pemerintah Daerah}

Menurut Yulk dikutip oleh Elisabeth (2005), kepemimpinan menyangkut proses sosial, pengaruh yang sengaja dijalankan oleh seseorang terhadap orang lain untuk menstruktur aktivitas - aktivitasnya serta hubungan - hubungan di dalam sebuah kelompok atau organisasi. Kepemimpinan, menurut Yulk (2005), menunjukkan dua dimensi gaya kepemimpinan, yaitu : 1) gaya kepemimpinan konsederasi, pemimpin bertindak dalam cara yang bersahabat dan mendukung, meperlihatkan perhatian terhadap bawahan dan memperhatikan kesejahteraan mereka, dan 2) gaya kepemimpinan Insiasi, pemimpin menentukan dan membuat struktur perannya sendiri dan peran bawahann ke pencapaian tujuan formal,contohnya meminta bawahan memenuhi prosedur standar perusahaan.

Gaya kepemimpinan yang positif dapat digunakan untuk meningkatkan kinerja SKPD dalam penanganan anggaran dan keuangan secara efektif. Ini sangat penting sebab kinerja bawahan banyak dipengaruhi oleh gaya kepemimpinan.

\section{Hubungan Komitmen, Kualitas Sumber Daya Manusia, Gaya Kepemimpinan terhadap Kemampuan Penyusunan Anggaran Pemerintah Daerah}

Dalam penyusunan anggaran Rendahnya komitmen mencerminkan kurangnya tanggung jawab seseorang dalam menjalankan tugasnya. Mempersoalkan komitmen sama dengan mempersoalkan tanggung jawab. Dalam kaitan dengan kemampuan penyusunan anggaran, maka efektif dalam penyusunan anggaran adalah sumber manusia yakni pegawai yang memiliki latar belakang pendidikan Akuntansi, Keuangan dan pegawai yang sudah memiliki pengalaman dengan waktu yang relatif lama di bidang penganggaran. Kepemimpinan yang berorientasi pada pencapaian : Mendorong para pegawai untuk berprestasi pada tingkat tertinggi mereka dengan menetapkan tujuan yang matang, menekankan pada kesempurnaan dan memperlihatkan kepercayaan diri atas kemampuan pegawai. Gaya kepemimpinan yang positif dapat digunakan untuk meningkatkan komitmen, sumber daya manusia, dengan gaya kepemimpinan yang positif meningkatkan kinerja SKPD dalam penanganan anggaran dan keuangan secara efektif.

\section{Penelitian Terdahulu}

Ali dan Hamid (2012), melakukan penelitian tentang Faktor-Faktor yang Mempengaruhi Penyusunan Anggaran Belanja dan Pendapatan Daerah berbasis Kinerja. Hasil penelitian tersebut menyimpulkan bahwa secara bersama-sama faktor komitmen dari seluruh komponen organisasi, penyempurnaan administrasi, sumberdaya yang cukup, penghargaan (reward) dan sanksi (punishment) berpengaruh positif dan signifikan terhadap penyusunan APBD berbasis kinerja. Secara parsial faktor komitmen dari seluruh komponen organisasi, penyempurnaan administrasi dan sanksi (punishment) berpengaruh positif dan signifikan terhadap penyusunan APBD berbasis kinerja.

Himawan (2010) melakukan penelitian tentang pengaruh Komitmen Organisasi, Gaya kepemimpinan dan Job Relevant Information terhadap Hubungan antara Partisipasi Anggaran dan Kinerja Manajerial, dari hasil penelitian menunjukkan bahwa gaya kepemimpinan yang berorientasi pada konsiderasi akan mampu meningkatkan pengaruh partisipasi penyusunan anggaran terhadap kinerja manajerial. Komitmen Organisasi dapat memoderasi pengaruh partisipasi anggaran terhadap kinerja manajerial.

\section{KERANGKA KONSEPTUAL} Kerangka Konseptual Penelitian

Penelitian ini menggambarkan bahwa komitmen pegawai pada organisasi dalam penyusunan anggaran tidak terjadi begitu saja, tetapi melalui proses panjang dan bertahap. Steers dikutip oleh sopiah $(2008 ; 20)$ faktor-faktor yang mempengaruhi komitmen seorang pegawai yaitu keyakinan, variasi 
kebutuhan, keinginan yang berbeda dari setiap pegawai, kesempatan berinteraksi dengan rekan sekerja, kewajiban.

Pada Gambar 3.1 terlihat adanya pengaruh kualitas sumber daya manusia terhadap kemampuan penyusunan anggaran, dengan adanya faktor manajemen sumber daya manusia yang dianggap memperjelas pengaruh kualitas sumber daya manusia terhadap kemampuan penyusunan anggaran.

Penelitian ini mengusulkan bahwa pemimpin yang berpartisipasi dalam proses penyusunan anggaran akan meningkatkan komitmen pegawai dalam penyusunan anggaran, sehingga akan memperbaiki penilaian kinerja terhadap masing-masing SKPD lebih baik. Adapun kerangka konseptual penelitian ini digambarkan pada Gambar 3.1 berikut ini.

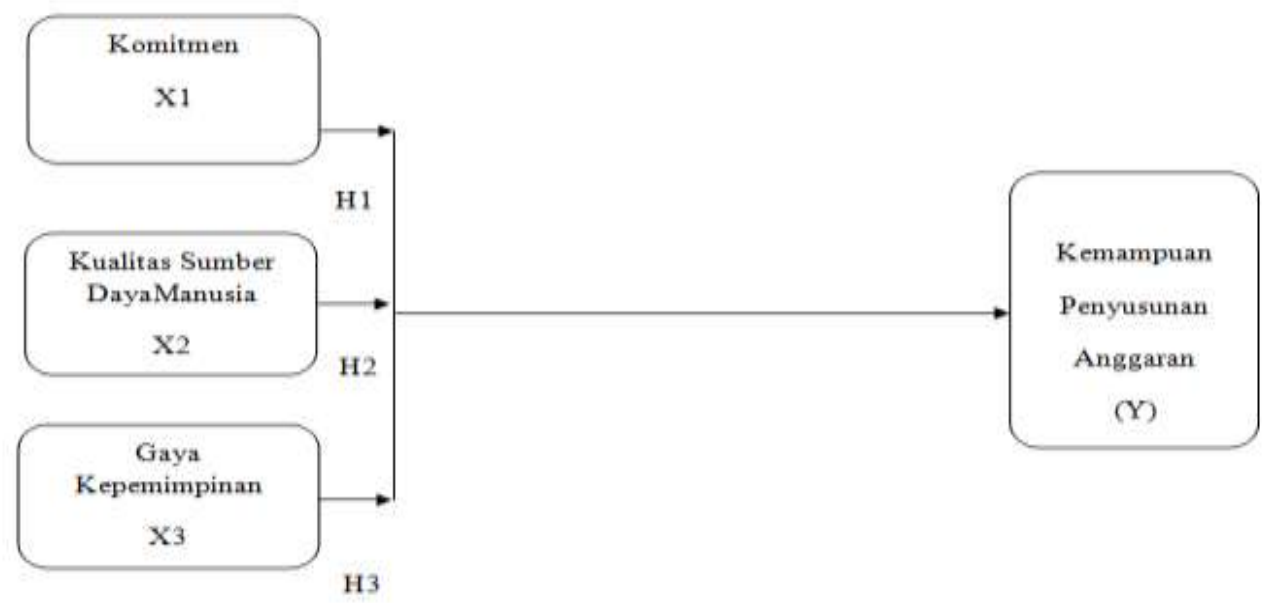

Gambar 3,1 Kerangka Konseptual

\section{Hipotesa}

Berdasarkan Pada Beberapa argumentasi diatas maka peneliti menetapkan hipotesis Kedua penelitian sebagai berikut :

H1 : Komitmen berpengaruh positif terhadap kemampuan penyusunan anggaran pemerintah daerah

$\mathrm{H} 2$ : Kualitas sumber daya manusia berpengaruh positif terhadap kemampuan penyusunan anggaran pemerintah daerah di Kota Manado

H3 : Gaya Kepemimpinan berpengaruh positif terhadap kemampuan penyusunan anggaran pemerintah daerah di Kota Manado.

\section{METODE PENELITIAN}

\section{Jenis Data}

Jenis data yang digunakan dalam penelitian ini terutama data kualitatif yang dikuantitatifkan. Menurut Sugiyono (2011) metode kuantitatif adalah cara ilmiah untuk mendapatkan data penelitian berupa angka-angka menggunakan statistik.

\section{Sumber Data}

Sumber data yang digunakan dalam penelitian ini adalah :

1. Data Primer yaitu berupa kuesioner yang diberikan kepada responden pada SKPD di Kota Manado.

2. Data Sekunder yaitu berupa literatur-literatur kepustakaan yang digunakan sebagai dasar teori yang relevan dengan masalah yang diteliti dan penelitian-penelitian sebelumnya.

\section{Populasi dan Sampel Penelitian}

Populasi adalah subjek yang mempunyai kuantitas dan karakteristik tertentu yang ditetapkan oleh peneliti untuk dipelajari dan kemudian ditarik kesimpulannya, ( Sugiyono, 2011). Populasi dalam penelitian ini adalah Pegawai SKPD (Dinas dan Badan) Kota Manado 
Pada penelitian ini Metode pengambilan sampel (sampling) yang digunakan adalah judgment sampling. Judgment sampling yaitu pengambilan sampel berdasarkan "penilaian" (judgment) peneliti mengenai siapa-siapa saja yang pantas (memenuhi persyaratan) untuk dijadikan sampel.

Sampel dari penelitian ini adalah Sekretaris, Kepala Bidang di masing-masing SKPD (Eselon III), kurang lebih 5 sampai 6 orang. Jadi jumlah sampel yang ditetapkan dalam penelitian ini sebanyak 100 responden.

\section{Definisi Operasional dan Pengukuran Variabel}

1. Komitmen, adalah sikap kesediaan diri untuk memegang teguh visi, misi serta kemauan untuk mengerahkan seluruh usaha dalam melaksanakan tugas.

2. Kualitas Sumber Daya Manusia, adalah kesatuan tenaga manusia sebagai suatu sistem di mana tiap-tiap karyawan berfungsi untuk mencapai tujuan organisasi. Sumber daya manusia diukur berdasarkan latar belakang pendidikan yang diperoleh pegawai.

3. Gaya Kepemimpinan, adalah Suatu perwujudan perilaku atau tingkah laku dari seorang pemimpin yang menyangkut kemampuannya dalam memimpin suatu dinas atau badan khususnya dalam dunia pemerintahan.

4. Kemampuan Penyusunan Anggaran, adalah Suatu rencana yang disusun secara sistematis yang meliputi seluruh kegiatan perusahaan atau SKPD, yang dinyatakan dalam unit (kesatuan) moneter dan berlaku untuk jangka waktu (periode) tertentu yang akan datang.

\section{METODE ANALISIS}

Model analisis data dalam penelitian ini adalah Analisis Regresi Linier Berganda dengan menggunakan program SPSS ( Statistical product dan service solution ) Version 20.00. Interpretasi model regresi linear berganda yang digunakan dalam penelitian ini adalah

Dimana :

$$
\mathbf{Y}=\alpha+\beta 1 X 1+\beta 2 \times 2+\beta 3 \times 3+€
$$

$\begin{array}{lll}\mathrm{Y} & = & \text { Kemampuan Penyusunan Anggaran } \\ \alpha & = & \text { Konstanta } \\ \beta, \beta 1, \beta 2, \beta 3 & = & \text { Koefisien Regresi } \\ \mathrm{X} 1 & = & \text { Komitmen } \\ \mathrm{X} 2 & = & \text { Sumber daya manusia } \\ \mathrm{X} 3 & = & \text { Gaya Kepemimpinan } \\ € & = & \text { Error }\end{array}$

\section{ANALISIS DAN PEMBAHASAN HASIL PENELITIAN \\ Hasil Penelitian \\ Statistik Deskriptif}

Dari 71 responden tentang masa kerja responden, sebanyak 2 responden $(2,82 \%)$ masa kerja antara 0 tahun -5 tahun, sebanyak 4 responden $(5,63 \%)$ masa kerja antara 6 tahun -10 tahun, sebanyak 16 responden $(22,54 \%)$ masa kerja 11 tahun - 15 tahun, sebanyak 17 responden $(23,94 \%)$ masa kerja 16 tahun - 20 tahun, dan sebanyak 32 responden (45,07\%) masa kerja lebih dari 21 tahun. Komposisi responden berdasarkan golongan pada pemerintah Kota Manado dapat dilihat pada Tabel 5.1.

Tabel 1 Komposisi Responden Berdasarkan Golongan

\begin{tabular}{|c|c|c|c|}
\hline NO & Golongan & Jumlah & Persentase \\
\hline 1 & III C & 8 & $11.27 \%$ \\
\hline 2 & III D & 27 & $38.03 \%$ \\
\hline 3 & IV A & 23 & $32.39 \%$ \\
\hline 4 & IV B & 13 & $18.31 \%$ \\
\hline \multicolumn{2}{|c|}{ Jumlah } & 71 & $100 \%$ \\
\hline
\end{tabular}

Sumber : Data Penelitian Telah Diolah, 2014 
Berdasarkan tabel 1 tersebut diatas dapat diketahui dari 71 responden tentang komposisi golongan, yakni sebanyak 8 responden (11,27\%) dengan golongan III C, sebanyak 27 responden $(38,03 \%)$ dengan golongan III D, sebanyak 23 responden (32,39\%) dengan golongan IV A dan sebanyak 13 responden $(18,31 \%)$ dengan golongan IV B. Komposisi responden berdasarkan tingkat pendidikan pada pemerintah kota manado dapat dilihat pada Tabel 2.

Tabel 2 Komposisi Responden Berdasarkan Tingkat Pendidikan

\begin{tabular}{|c|c|c|c|}
\hline No & Tingkat Pendidikan & Jumlah & Persentase \\
\hline 1 & D3 Akuntansi & - & $0 \%$ \\
\hline 2 & D3 Non Akuntansi & - & $0 \%$ \\
\hline 3 & S1 Akuntansi & 4 & $5.63 \%$ \\
\hline 4 & S1 Non Akuntansi & 58 & $81.69 \%$ \\
\hline 5 & S2 Akuntansi & 2 & $2.82 \%$ \\
\hline 6 & S2 Non Akuntansi & 7 & $9.86 \%$ \\
\hline \multicolumn{2}{|c|}{ Jumlah } & 71 & $100 \%$ \\
\hline
\end{tabular}

Sumber : Data Penelitian Telah Diolah, 2014

Berdasarkan tabel 2 diatas dapat diketahui dari 71 responden tentang komposisi tingkat pendidikan, yakni sebanyak 4 responden $(5,63 \%)$ dengan tingkat pendidikan S1 Akuntansi, sebanyak 58 responden (81,69\%) dengan tingkat pendidikan S1 Non Akuntansi, sebanyak 2 responden $(2,82 \%)$ dengan tingkat pendidikan S2 Akuntansi, dan sebanyak 7 responden $(9,86 \%)$ dengan tingkat pendidikan S2 Non Akuntansi.

Hasil jawaban responden dalam menjawab setiap pertanyaan yang sudah dimodifikasi tentang Pengaruh Komitmen, Kualitas Sumber Daya Manusia, Gaya Kepemimpinan Terhadap Kemampuan Penyusunan Anggaran pada SKPD di Pemerintah Kota Manado telah dirangkum dalam tabulasi data dengan menggunakan program Microsoft Excel.

Untuk variabel $\mathrm{X}_{1}$ (Komitmen) terdapat 6 pertanyaan, untuk variabel $\mathrm{X}_{2}$ (Kualitas Sumber Daya Manusia) terdapat 5 pertanyaan, untuk variabel $X_{3}$ (Gaya Kepemimpinan) terdapat 6 pertanyaan dan variabel Y (Kemampuan Penyusunan Anggaran) terdapat 4 pertanyaan sehingga total keseluruhan berjumlah 21 pernyataan.

\section{Analisis Regresi Linier Berganda}

Berdasarkan hasil perhitungan dan pengolahan data dengan menggunakan program SPSS Version 20.0, maka hasil perhitungan analisis regresi berganda dapat dilihat dalam Tabel 3

Tabel 3

Coefficients $^{\mathrm{a}}$

\begin{tabular}{|c|c|c|c|c|c|c|}
\hline \multirow{2}{*}{\multicolumn{2}{|c|}{ Model }} & \multicolumn{2}{|c|}{$\begin{array}{c}\text { Unstandardized } \\
\text { Coefficients }\end{array}$} & \multirow{2}{*}{$\begin{array}{c}\text { Standardized } \\
\text { Coefficients } \\
\text { Beta } \\
\end{array}$} & \multirow[t]{2}{*}{$\mathrm{t}$} & \multirow[t]{2}{*}{ Sig. } \\
\hline & & B & Std. Error & & & \\
\hline \multirow{4}{*}{1} & (Constant) & 13.387 & 2.363 & & 5.666 & .000 \\
\hline & $\mathrm{x} 1$ & -.015 & .078 & -.023 & -.198 & .844 \\
\hline & $\mathrm{x} 2$ & -.162 & .112 & -.202 & -1.451 & .151 \\
\hline & $\mathrm{x} 3$ & .329 & .097 & .467 & 3.378 & .001 \\
\hline
\end{tabular}

a. Dependent Variabel: Y

Dari Tabel 3 Model Regresi Linier Berganda dalam penelitian ini adalah Y = 13.387 - 0.015 X1 0.162 X2 + 0.329 X3. Nilai $\beta_{1}$ yang merupakan koefisien regresi dari variabel $X_{1}$ (Komitmen) tanda negatif (-) mempunyai arti bahwa kurangnya komitmen dalam penyusunan anggaran dalam setiap SKPD, maka kinerja aparat Pemerintah Kota Manado akan mengalami penurunan. 
Selanjutnya, Nilai $\beta_{2}$ merupakan koefisien regresi dari variabel $\mathrm{X}_{2}$ (Kualitas sumber daya manusia) tanda negatif (-) mempunyai arti bahwa semakin rendah kualitas sumber daya manusia yang ada di masing-masing SKPD Kota Manado dalam penyusunan anggaran, maka akan berkurangya kualitas anggaran dalam setiap SKPD dan penurunan dalam pemberian penilaian terhadap penyusunan anggaran berbasis kinerja pada pemerintah Kota Manado.

Sedangkan nilai $\beta_{3}$ yang merupakan koefisien regresi dari variabel $X_{3}$ (Gaya kepemimpinan) tanda positif (+) berarti bahwa dengan Gaya kepemimpinan yang positif dapat memotivasi pejabat penyusun anggaran di SKPD sehingga dapat menghasilkan anggaran yang berkualitas dan sesuai dengan pedoman penyusunan anggaran daerah, dengan demikian hal ini akan meningkatkan kinerja dari SKPD kota Manado dan peningkatan pemberian hasil penilaian terhadap kinerja pemerintah Kota Manado lebih baik lagi.

Berdasarkan nilai koefisien regresi dapat diketahui bahwa ternyata faktor gaya kepemimpinan lebih dominan berpengaruh terhadap kinerja aparat pemerintah Kota Manado dalam penyusunan anggaran apabila dibandingkan dengan faktor komitmen dan sumber daya manusia.

\section{Pengujian Hipotesis}

\section{Uji Koefisien Regresi secara bersama-sama (Uji F)}

Uji F dilakukan untuk mengetahui apakah variabel-variabel independen Komitmen (X1), Kualitas Sumber Daya Manusia (X2), dan Gaya Kepemimpinan (X3) secara bersama-sama mempunyai pengaruh terhadap Variabel dependen yaitu : Kemampuan Penyusunan Anggaran (Y). Dari hasil output uji koefisien regresi secara bersama-sama (Uji F) dapat diketahui nilai F seperti pada Tabel 4.

\section{Tabel 4 Hasil Uji F}

ANOVA $^{\mathrm{a}}$

\begin{tabular}{|l|r|r|r|r|r|}
\hline Model & \multicolumn{1}{|c|}{$\begin{array}{c}\text { Sum of } \\
\text { Squares }\end{array}$} & df & Mean Square & F & Sig. \\
\hline Regression & 42.757 & 3 & 14.252 & 3.906 & $.012^{\mathrm{b}}$ \\
Residual & 244.482 & 67 & 3.649 & & \\
Total & 287.239 & 70 & & & \\
\hline
\end{tabular}

a.Dependent Variabel : Kemampuan Penyusunan Anggaran

b.Predictors (Constant): Komitmen, Kualitas Sumber Daya

Manusia, Gaya Kepemimpinan

Berdasarkan tabel 4, hasil uji $\mathrm{F}$ diperoleh $\mathrm{F}_{\text {hitung }}$ sebesar 3,906 dengan menggunakan tingkat signifikan $\mathrm{P}=0,012<\alpha=0,05$ maka dapat disimpulkan bahwa variabel Komitmen $\left(\mathrm{X}_{1}\right)$, Kualitas Sumber Daya Manusia $\left(\mathrm{X}_{2}\right)$, dan Gaya Kepemimpinan $\left(\mathrm{X}_{3}\right)$ secara bersama-sama mempunyai pengaruh terhadap Variabel dependen yaitu : Kemampuan Penyusunan Anggaran pada SKPD di Kota Manado.

Uji t

Uji Parsial (Uji t) dilakukan untuk mengetahui pengaruh variabel independen secara individual terhadap variabel dependen. Tabel 5 adalah tabel analisis regresi linier sederhana.

Tabel 5

Coefficients $^{\mathrm{a}}$

\begin{tabular}{|c|c|c|c|c|c|c|}
\hline \multirow{2}{*}{\multicolumn{2}{|c|}{ Model }} & \multicolumn{2}{|c|}{$\begin{array}{l}\text { Unstandardized } \\
\text { Coefficients }\end{array}$} & $\begin{array}{l}\text { Standardized } \\
\text { Coefficients }\end{array}$ & \multirow[t]{2}{*}{$\mathrm{t}$} & \multirow[t]{2}{*}{ Sig. } \\
\hline & & $\mathrm{B}$ & Std. Error & Beta & & \\
\hline \multirow{4}{*}{1} & (Constant) & 13.387 & 2.363 & & 5.666 & .000 \\
\hline & $\mathrm{x} 1$ & -.015 & .078 & -.023 & -198 & .844 \\
\hline & $\mathrm{x} 2$ & -.162 & .112 & -.202 & -1.451 & . 151 \\
\hline & $\mathrm{x} 3$ & .329 & .097 & .467. & 3.378 & .001 \\
\hline
\end{tabular}

a. Dependent Variabel: Y 
Pengujian hipotesis pada uji t untuk mengetahui pengaruh variabel independen terhadap variabel dependen secara individual (parsial) dengan menggunakan kriteria yaitu apabila signifikan $<0.05$ maka Ho ditolak, Ha diterima dan apabila signifikan > 0.05 maka Ho diterima dan Ha ditolak.

\section{Koefisien Determinasi $\left(\mathbf{R}^{2)}\right.$ \& Koefisien Korelasi $(\mathbf{R})$}

Hasil analisa koefisien determinasi dan koefisien korelasi dapat dilihat dalam Tabel 5.14 berikut ini :

Tabel 6

Model Summary ${ }^{\mathrm{b}}$

\begin{tabular}{|l|r|r|r|r|}
\hline Model & R & R Square & Adjusted R Square & $\begin{array}{c}\text { Std. Error of the } \\
\text { Estimate }\end{array}$ \\
\hline 1 & $.386^{\mathrm{a}}$ & .149 & .111 & 1.91023 \\
\hline
\end{tabular}

a. Predictors: (Constant), $\mathrm{X}_{1}, \mathrm{X}_{2}, \mathrm{X}_{3}$

b. Dependent Variabel: anggaran (y)

Dari Tabel 6 Koefisien determinasi $\left(\mathrm{R}^{2}\right)$ sebesar 0.149 yang memiliki arti bahwa pengaruh variabel bebas $\mathrm{X}_{1}, \mathrm{X}_{2}$, dan $\mathrm{X}_{3}$ terhadap perubahan variabel terikat $\mathrm{Y}$ adalah sebesar $14.9 \%$ dan sisanya dipengaruhi oleh variabel lain di luar variabel bebas yang digunakan dalam penelitian ini.

Koefisien korelasi (R) pada Tabel 5.14 sebesar 0.386 menunjukkan bahwa hubungan variabel $\mathrm{X}_{1}$, $\mathrm{X}_{2}$, dan $\mathrm{X}_{3}$ terhadap variabel terikat $\mathrm{Y}$ adalah kuat. Nilai koefisien $\mathrm{R}$ yang positif menunjukkan pengaruh hubungan yang searah atau jika nilai variabel bebas naik maka nilai variabel terikat juga naik.

\section{Pembahasan Hasil Penelitian}

\section{Pengaruh Komitmen terhadap Kemampuan Penyusunan Anggaran}

Variabel Komitmen $\left(\mathrm{X}_{1}\right)$ tidak berpengaruh signifikan terhadap kemampuan aparatur terkait dalam menyusun anggaran masing-masing SKPD. Hal ini disebabkan karena pejabat pengelola keuangan daerah di Kota Manado tidak mengetahui secara utuh apa yang menjadi wewenang dan tanggung jawab sehingga setiap ada perubahan dalam peraturan tidak siap untuk melaksanakan penyusunan anggaran yang semestinya harus sesuai dengan pedoman pengelolaan keuangan daerah yang sudah ditetapkan,sehingga dapat disesuaikan dengan waktu pelaporan anggaran tersebut. Tanpa komitmen maka harapan-harapan, prestasi akan sulit dicapai,penyusunan anggaran adalah hal yang penting dalam SKPD, karena salah satu penilaian kinerja pemerintah adalah tepat tidaknya penyusunan anggaran dan sesuai dengan pedoman, apabila pelaporan anggaran tepat waktu dan sesuai dengan pedoman yang telah ditetapkan, maka penilaian yang akan diberikan ke masing-masing SKPD adalah baik dengan demikian tercapai sebuah prestasi yang membanggakan dan dapat dijadikan teladan.

\section{Pengaruh Kualitas Sumber Daya Manusia terhadap Kemampuan Penyusunan Anggaran}

Pada penelitian ini bahwa secara parsial Variabel Kualitas sumber Daya Manusia $\left(\mathrm{X}_{2}\right)$ tidak berpengaruh signifikan terhadap Kemampuan Penyusunan Anggaran masing-masing SKPD. Hal ini disebabkan karena dalam penyusunan anggaran tidak hanya bergantung sepenuhnya pada kualitas sumber daya manusia, ada sumber-sumber daya lain seperti sumber daya anggaran, informasi berupa data dan fasilitas pendukung lainnya.dalam pelaporan anggaran, masih ditemukan pengalokasian anggaran yang tidak sesuai dengan kebutuhan dan skala prioritas serta kurang mencerminkan aspek ekonomis, efisiensi dan efektivitas.

\section{Pengaruh Gaya Kepemimpinan terhadap Kemampuan Penyusunan Anggaran}

Hasil Penelitian ini menyatakan bahwa variabel Gaya Kepemimpinan $\left(\mathrm{X}_{3}\right)$ berpengaruh terhadap kemampuan penyusunan anggaran. Dengan adanya kepedulian dari atasan untuk memberikan petunjuk yang baik dan benar mengenai penyusunan anggaran, memberikan perhatian dari setiap masalah yang ada pada SKPD, adanya hubungan yang baik dalam hal dimintai saran oleh atasan, sehubungan dengan penyusunan anggaran, maka akan dihasilkan anggaran yang berkualitas sesuai dengan pedoman yang 
sudah ditetapkan. Hasil penelitian ini sependapat dengan Penelitian sebelumnya yang dilakukan oleh Sumarno (2005).

\section{Pengaruh Komitmen, Kualitas Sumber Daya Manusia, Gaya Kepemimpinan terhadap Kemampuan Penyusunan Anggaran}

Berdasarkan hasil pengujian dengan Uji F, yang bertujuan untuk mengetahui apakah ada pengaruh dari 3 variabel independen secara bersama-sama terhadap variabel dependen. Dan ternyata variabel Komitmen $\left(\mathrm{X}_{1}\right)$, Kualitas Sumber Daya Manusia $\left(\mathrm{X}_{2}\right)$, dan Gaya Kepemimpinan $\left(\mathrm{X}_{3}\right)$ secara bersamasama mempunyai pengaruh terhadap Variabel dependen yaitu : Kemampuan Penyusunan Anggaran pada SKPD di Kota Manado. Hal ini menunjukkan bahwa komitmen, kualitas sumber daya manusia, dan gaya kepemimpinan mempengaruhi kemampuan penyusunan anggaran pemerintah daerah Kota Manado lebih berkualitas, dengan kualitas sumber daya manusia yang baik maka akan meningkatkan pengetahuan, sehingga dapat mengerjakan tugas dan tanggung jawabnya lebih baik dari sebelumnya, hal ini ditunjang dengan gaya kepemimpinan yang selalu mendukung untuk hal-hal positif yang dikerjakan dan memotivasi timbulnya komitmen untuk mewujudkan tujuan yang sudah ditetapkan, sehingga penilaian akan kinerja yang baik dapat diterima oleh masing-masing SKPD yang menunjukkan kinerja yang baik terhadap tugas dan tanggung jawabnya.

\section{KESIMPULAN DAN SARAN \\ Kesimpulan} berikut :

Dari hasil dan analisis statistik dalam penelitian ini, maka diambil kesimpulan antara lain sebagai

1. Hasil studi menunjukkan Komitmen secara parsial tidak berpengaruh terhadap penyusunan anggaran SKPD pemerintah Kota Manado, Dalam hal ini persepsi responden menunjukkan dalam penyusunan anggaran dan keberhasilannya kepada atasan dan kepuasan diri sendiri. pengalokasian anggaran yang tidak sesuai dengan kebutuhan dan skala prioritas serta kurang mencerminkan aspek ekonomis, efisiensi dan efektivitas.

2. Untuk variabel Sumber Daya Manusia secara parsial tidak berpengaruh terhadap variabel kemampuan penyusunan anggaran, artinya penyusunan anggaran tidak hanya bergantung sepenuhnya pada kualitas sumber daya manusia, ada sumber-sumber daya lain berupa barang modal termasuk peralatan dan teknologi, dana atau kombinasi dari beberapa atau kesemua jenis sumberdaya yang digunakan untuk melaksanakan kegiatan.

3. Hasil pengujian uji parsial atau uji t Gaya Kepemimpinan berpengaruh terhadap penyusunan anggaran, artinya seorang pemimpin yang memberikan arahan yang baik, peduli dengan permasalahan yang ada, menegur dengan santun bawahan yang tidak menjalankan tugas sesuai dengan prosedur, maka akan menghasilkan anggaran yang berkualitas.melalui penelitian ini banyak responden yang menyatakan tidak menyetujui hasil pekerjaan tidak diperiksa dan langsung ditandatangani, artinya pemeriksaan atasan terhadap hasil kerja bawahan sangat penting dan berpengaruh untuk memotivasi menyusun anggaran dengan baik dan benar.

4. Dengan Hasil uji F disimpulkan bahwa variabel Komitmen $\left(\mathrm{X}_{1}\right)$, Kualitas Sumber Daya Manusia $\left(\mathrm{X}_{2}\right)$, dan Gaya Kepemimpinan $\left(\mathrm{X}_{3}\right)$ secara bersama-sama mempunyai pengaruh terhadap Variabel dependen, dan positif. Hal ini menunjukkan pengaruh hubungan yang searah atau jika nilai variabel bebas naik maka nilai variabel terikat juga naik. Dengan adanya kualitas sumber daya manusia yang baik maka akan meningkatkan pengetahuan, sehingga dapat mengerjakan tugas dan tanggung jawabnya lebih baik dari sebelumnya, hal ini ditunjang dengan gaya kepemimpinan yang selalu mendukung untuk hal-hal positif yang dikerjakan dan memotivasi timbulnya komitmen untuk mewujudkan tujuan yang sudah ditetapkan, sehingga penilaian akan kinerja yang baik dapat diterima oleh masing-masing SKPD yang menunjukkan kinerja yang baik terhadap tugas dan tanggung jawabnya.

\section{Saran}

Dari Hasil penelitian yang ada, maka saran yang dapat diberikan adalah sebagai berikut. 
1. Penelitian berikutnya harus mempertimbangkan karakteristik atau variabel lain yang mempengaruhi penyusunan anggaran, misalkan harga pasar, pendapat masyarakat, alam.

2. Peneliti menyarankan untuk penelitian selanjutnya agar memperluas objek penelitian pada SKPD se-provinsi Sulut sehingga hasilnya dapat digeneralisasi. Dan untuk sampel penelitian dari eselon II

3. Memberikan tambahan informasi untuk penelitian selanjutnya sehingga dapat membantu pengembangan Ilmu Akuntansi khususnya Akuntansi sektor publik

4. Bagi Pemerintah Daerah Kota Manado, dalam penyusunan anggaran diperlukan partisipasi semua pimpinan SKPD bukan partisipasi yang semu, agar menghasilkan anggaran yang berkualitas, artinya merencanakan program kegiatan di Rencana Kerja Anggaran (RKA) sesuai kemampuan anggaran bukan kebutuhan, tapi memprioritaskan kegiatan untuk masyarakat dan sesuai dengan ketentuan yang berlaku.

\section{DAFTAR PUSTAKA}

Adisasmita, Rahardjo, 2011, Pengelolaan Pendapatan dan Anggaran Daerah, Graha Ilmu, Yogyakarta.

Albertus Kukuh Himawan, 2010, Pengaruh Komitmen Organisasi, Gaya Kepemimpinan dan Kinerja Manajerial.

Bastian, Indra. 2006. Sistem Akuntansi Sektor Publik, Salemba Empat Jakarta

Darise, Nurlan, 2009, Pengelolaan Keuangan Daerah, Edisi 2, Indeks, Jakarta

Data Jumlah Pegawai SKPD Kota Manado, tahun 2014 ( Bkd.manadokota.go.id)

Darlisman Dalmy, 2013, Pengaruh Sumber Daya Manusia, Komitmen, Motivasi terhadap Kinerja Auditor dan Reward sebagai Variabel Moderating pada Inspektorat Provinsi Jambi.

Hetifah Sj. Sumarto, 2003, Inovasi, Partisipasi dan Good Governance, Yayasan Obor Indonesia, Jakarta Halim, Abdul, 2010, Sistem Akuntansi Sektor Publik, Edisi pertama, UPP STIM YKPN.

Haryadi Sarjono, Winda Julianita, 2013, SPSS vs Lisrel, Sebuah Pengantar Aplikasi untuk Riset, Salemba Empat.

Irianto H. Agus, 2004. Statistik : Konsep Dasar dan Aplikasinya. Cetakan Kedua, Penerbit PT.Prenada Media, Jakarta

Mardiasmo, 2009, Akuntansi Sektor Publik, Andi, Yogyakarta

Mochammad, Solichin, 2009. Pengaruh Kejelasan Sasaran Anggaran terhadap Kinerja Anggaran Pemerintah Daerah Yogyakarta. (tesis)

,Permendagri Nomor 13 Tahun 2006 tentang Pengelolaan Keuangan Daerah, Jakarta ,Permendagri Nomor 59 Tahun 2007 tentang Pengelolaan Keuangan Daerah, Jakarta 